\title{
Neurological Manifestations of COVID-19 patients: An Updated Review and Observations of COVID Patients in the National Institute of Neurosciences and Hospital, Dhaka, Bangladesh
}

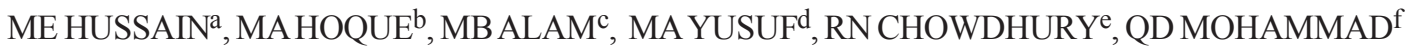

\begin{abstract}
Summary:
Involvement of the nervous system after viral infection is common. Certain viruses show neurotropism. Recent outbreak of severe acute respiratory syndrome CoV 2 (SARSCov-2) virus has also exhibited neurotropic properties with various neurological manifestations. The pathophysiology of their neurotropism is not yet clearly known. The details of pathophysiology, clinical manifestation and management
\end{abstract}

Conflict of interest: None.Contribution of authors: $\mathrm{MEH}$ was involved in writing the manuscript, $\mathrm{AH}$ was involved in supervison, planning and manuscript revision, BA and RNC were involved in the revision of the manuscript, MAY helped in statistical analysis and data collection, QDM was the supervisor and guide.

\section{Introduction:}

Corona virus disease 2019 (COVID-19) caused by SARSCov-2 virus, first emerged from Wuhan city, Hubei province of China ${ }^{1,2}$. The World health organization

a. Dr. Mohammad Enayet Hussain, Associate Professor, Department of Neurology, National Institute of Neurosciences \& Hospital, Dhaka, Bangladesh.

b. Prof. Md. Azharul Hoque, Professor of Neurology and Head, Department of Neurology, National Institute of Neurosciences \& Hospital, Dhaka, Bangladesh.

c. Prof. Md. Badrul Alam, Joint director and Professor of Neurology, Department of Neurology, National Institute of Neurosciences \& Hospital, Dhaka, Bangladesh.

d. Dr. Md. Abdullah Yusuf, Assistant Professor, Department of Microbiology, National Institute of Neurosciences \& Hospital, Dhaka, Bangladesh.

e. Dr. Rajib Nayan Chowdhury, Associate Professor, Department of Neurophysiology, National Institute of Neurosciences \& Hospital, Dhaka, Bangladesh.

f. Prof. Quazi Deen Mohammad, Director and Professor of Neurology, Department of Neurology, National Institute of Neurosciences \& Hospital, Dhaka, Bangladesh.

Address of Correspondence: Mohammad Enayet Hussain, Associate Professor, Department of Neurology, National Institute of Neurosciences \& Hospital, Dhaka, Bangladesh. Mobile No: 01716215871. are expected to be explored in the near future. Here we review the Neurological manifestations of COVID-19 and the early experience in the National Institute of Neurosciences and Hospital.

Keywords COVID-19, Neurological manifestation, Stroke, Encephalitis, GBS

(J Bangladesh Coll Phys Surg 2020; 38: 122-132) DOI: https://doi.org/10.3329/jbcps.v38i0.47869

(WHO) China Country Office on 31 December 2019, was informed of cases of pneumonia of unknown etiology ${ }^{3}$ which on $11^{\text {th }}$ March 2020 was declared as a pandemic by $\mathrm{WHO}^{4}$. Since the detection COVID-19, hundreds of manuscripts have been published on the disease in different journals ${ }^{5}$. With the progression of time numerous data on different aspects of the disease such as manifestations, pathology, transmission, prevention, and management strategies have started to emerge ${ }^{6,7}$, 8 . Although initially it was thought to involve primarily the respiratory system like other coronaviruses, e.g. severe acute respiratory syndrome (SARS) and the Middle East Respiratory Syndrome (MERS), later it was found to have involved other systems as well including the nervous system ${ }^{9,10}$.

This article contains a descriptive review of the neurological manifestations and complications of COVID-19 with an aim to update the neurologists and physicians working with suspected cases of COVID-19 infection.

Medline, PubMed Central and Google Scholar using keywords "COVID-19", "Coronavirus", "SARS-Cov2", "Neurology", "Neurological”, "complications" and "manifestations" were searched and was limited only to English language manuscripts with no time limit. It consists mostly of pre-prints, case reports, small case series, and part of an article describing clinical features of COVID-19 and some review articles as well. 


\section{Pathogenesis Mechanism of involvement of the nervous system}

Corona viruses, especially ${ }^{2}$ coronaviruses to which the SARS CoV 2 belongs are not primarily neurotropic, rather their primary target is respiratory epithelium. The target receptor for attachment to cell and subsequent internalization is through the angiotensin converting enzyme-2 receptor (ACE 2) located abundantly in lung alveolar epithelial cells, enterocytes of the small intestine, arterial and venous endothelial cells and arterial smooth muscle cells in all organs. After entry into the cell the virus RNA is released in the cytoplasm which is subsequently translated and replicated. After formation of envelope protein and incorporation of RNA into the virus it is released in the circulation ${ }^{11}$.

ACE 2 receptors are also found in the neurons and glial cells in brain and spinal cord. These receptors are abundant in the brain stem and in the regions responsible for regulation of cardiovascular function including subfornical organ, paraventricular nucleus, nucleus of the tractus solitarius, and rostral ventrolateral medulla ${ }^{12}$. So the virus can attach, multiply and damage the neuronal tissue. There are several postulated mechanisms. Firstly, experiments in mice showed that the coronavirus enters the brain through a retrograde transfer via the olfactory epithelium or through the cribriform bone and reaches the brain in seven days' time. Secondly, during the viremia phase of illness, disruption of blood brain barrier causes the virus to enter the brain directly. Thirdly, the invasion of peripheral nerve terminals by $\mathrm{CoV}$ which then gains entry to the CNS through the synapse connected route. Since COVID-19 has similarities with Severe Acute Respiratory Syndrome (SARS Cov), it is presumed that it also follows the same pathways for CNS invasion as discussed above $\mathrm{e}^{11,12,13}$

\section{Mechanism of damage to the nervous system:}

Two mechanisms have been implicated for neurological damage. Firstly, severe pneumonia causes systemic hypoxia resulting in neuronal swelling and brain edema which ultimately results in neurological damage. The contributory factors here are peripheral vasodilatation, hypercarbia, hypoxia and anaerobic metabolism with accumulation of toxic compounds. If the hypoxia continues unabated, cerebral edema and the cerebral circulation disorder may worsen sharply. With intracranial hypertension, the brain function gradually deteriorates resulting in drowsiness, bulbar conjunctival edema, and even coma. In addition, for patients at particular risk of developing cerebrovascular disease, hypoxia may also induce the occurrence of acute cerebrovascular disease such as acute ischemic stroke ${ }^{14}$. Secondly, cytokine storms with increased levels of inflammatory cytokines and activation of $\mathrm{T}$ lymphocytes, macrophages, and endothelial cells lead to immune mediated injury. Hypercytokinemia causes vascular leakage, activation of complement and coagulation cascade, disseminated intravascular coagulation and end organ damage ${ }^{15,16}$.

\section{Neurological manifestations}

Most of the knowledge about neurological manifestations of COVID-19 so far gained, largely comes from few case series from China and one ICU-based observational study from France ${ }^{17-24}$ along with some individual case reports ${ }^{25-}$ 30. The important neurological manifestations and complications of COVID-19 reported in literature so far are summarized in Fig 1 . There are 2 case series specifically describing neurological manifestations and complications in COVID-19 patients (Table 1). The first is a retrospective case series on neurological manifestation from China by Mao et $\mathrm{al}^{17}$. They reported the patients in two groups. The severely ill group had $88(41.1 \%)$ patients while there were $126(58.9 \%)$ patients in the non-severely ill group. Patients in the severely ill group were significantly older (58.2 \pm 15 years vs. $48.9 \pm 14.7$ years) with more comorbid conditions especially hypertension [32 (36.4\%) vs. $19(15.1 \%)]$. Surprisingly the severely ill group had less typical symptoms of coronavirus like fever [40 (45.5\%) vs. $92(73 \%)$ ] and dry cough [30 (34.1\%) vs. 77 (61.1\%)]. However, nervous system symptoms were significantly more common in severe cases as compared with nonsevere cases $[40(45.5 \%)$ vs. $38(30.2 \%)]$. The most common CNS symptoms reported were dizziness [36 $(16.8 \%)$ and headache [28 (13.1\%)].

The second article is a prospective case series of 58 patients from France ${ }^{19}$. The median age of patients was 63 years and neurological complications were seen in a higher percentage 49/58 (84\%). As assessed by confusion Assessment method for intensive care unit CAM-ICU scale, agitation was the most common symptoms 40/58 (69\%) followed by confusion 26/40 (65\%). Corticospinal tract signs were present in in 39/58 $(67 \%)$ and a dysexecutive syndrome at the time of discharge was noted in14/39 (36\%). 
Table-I

\section{Comparison of Neurological complications and manifestations between the severely} ill Chinese and French patient series.

Variable

Study design

Total Number of cases

Number of seriously ill patients

Median Age (Years)

Neurological Involvement

Dizziness

Headache

Impaired consciousness

Hypogeusia

Hyposmia

Skeletal muscle injury

Simplified Acute Physiology

\section{Score II}

Agitation

Delirium as documented by CAM-ICU

Corticospinal tract signs

Dysexecutive syndrome at discharge Ischemic stroke

Hemorrhagic Stroke

Leptomeningeal enhancement on MRI

EEG
Mao et al. ${ }^{17}$

Retrospective Chart Review

214

88

58.7

$45.5 \%$

$19.3 \%$

$17.1 \%$

$14.8 \%$

$5.6 \%$

$5.1 \%$

$19.3 \%$

NR

NR

NR

NR

NR

$5(5.7 \%)$

1 (1.13)

NR

NR
Helms et al. ${ }^{19}$

Prospective Observational study Prospective Observa

58

63

$84 \%$

NR

NR

NR

NR

NR

NR

52

$40(69 \%)$

$26(65 \%)$

$39(67 \%)$

$14(36 \%)$

$3 / 13(23 \%)$

Nil

$8 / 13(62)$

1(8) diffuse bifrontal slowing

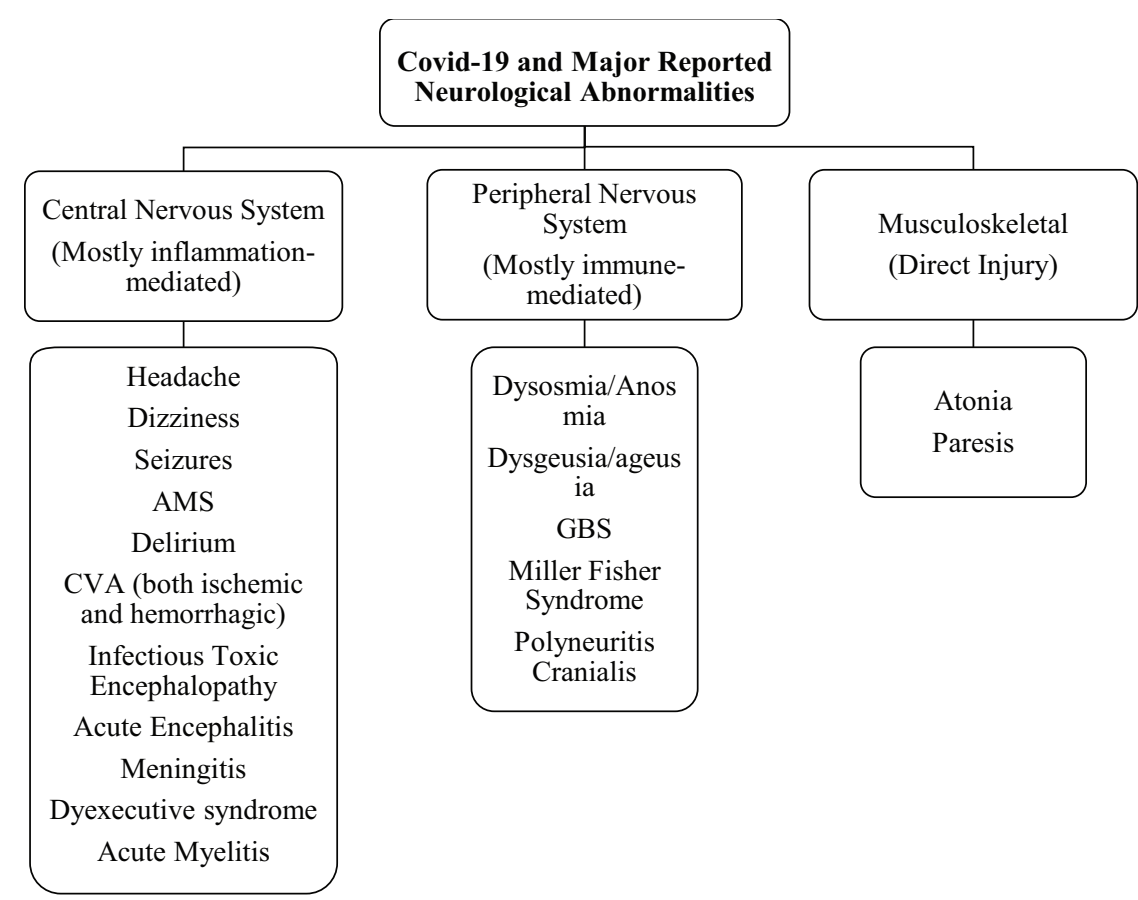

Fig.-1: Summary of major neurological abnormalities in COVID-19 


\section{Central nervous system manifestations:}

\section{Encephalopathy:}

Mao et $\mathrm{al}^{17}$ reported headache and encephalopathy in $40 \%$ of patients in their cohort but the details and the diagnostic criteria used was not described. Filatov et $\mathrm{al}^{25}$ reported the case of a 74-year-old man who was COVID-19 positive and presented with encephalopathy. The CT scan of head and cerebrospinal fluid (CSF) studies were negative for any infection. EEG showed evidence of encephalopathy, focal temporal lobe dysfunction, and possible elliptogenicity. Chen et $\mathrm{al}^{31}$ in a retrospective study of the clinical characteristics of 113 COVID-19 patients from China, documented hypoxic encephalopathy in 20 patients.

Acute hemorrhagic necrotizing encephalopathy (ANE) Poyiadji et al. ${ }^{29}$ reported the case of a female in her late 50 s who presented with altered mental status (AMS), besides fever and cough. Polymerase chain reaction (PCR) assay was positive for COVID-19 and negative for Herpes Simplex Virus 1 and 2, West Nile and Varicella Zoster Virus. Noncontrast CT scan of the head showed symmetric hypo-attenuation within the bilateral medial thalami and MRI demonstrated hemorrhagic rim enhancing lesions within the bilateral thalami, medial temporal lobes, and sub insular regions with a normal CT angiogram and CT venogram. Based on these findings the patient was diagnosed with acute hemorrhagic necrotizing encephalopathy (AHNE) and was treated with intravenous immunoglobulins (IV IgG) but the outcome was not mentioned. ANE is a rare complication of viral infections like influenza. The proposed mechanism is likely due to cytokine storm which results in disruption of blood brain barrier and damage to the brain parenchyma.

\section{Encephalitis}

The first confirmed case of COVID-19 associated viral meningo-encephalitis was reported by Moriguchi et al from Japan ${ }^{27}$. A 24 Years old male presented with fever followed by seizure and unconsciousness. He had neck stiffness. CT scan brain which was normal. CT chest revealed patchy opacities. PCR assay from nasopharyngeal swab was negative but CSF sample was positive for COVID-19.The Diffusion weighted images (DWI) showed hyperintensity along the wall of inferior horn of right lateral Ventricle.
Fluid-attenuated inversion recovery (FLAIR) images showed hyperintense signal changes in the right mesial temporal lobe and hippocampus with slight hippocampal atrophy mainly on right mesial lobe and hippocampus. There was no post contrast enhancement. The authors concluded that imaging findings were suggestive of right lateral ventriculitis and encephalitis. This case and presentation should alert clinicians regarding the neuroinvasive potential of COVID-19 and encephalitis like presentation.

\section{Cerebrovascular disease}

Sharifi et $\mathrm{al}^{30}$ from Iran reported a case of intracranial bleeding resulting in CVA in a 79 Years old COVID-19 positive male. He was admitted in the emergency in a semi-conscious state (Glasgow Coma Scale 7/15) with history of fever and cough. On examination there was, bilateral extensor planter response with coarse crepitation in left lower zones. PCR assay from nasopharyngeal secretion was positive for COVID-19. CT scan chest showed ground glass opacity suggestive of viral pneumonia. $\mathrm{CT}$ scan brain revealed a massive bleed within the right hemisphere with intraventricular and subarachnoid extension. This gentleman was neither a known hypertensive nor on any anticoagulants that could have caused this event. The platelets and PT/INR on admission were normal. The authors hypothesized that brain ACE II receptors could be involved in COVID-19 infection and its dysfunction, leading to disruption of autoregulation as well as blood pressure spikes due to arterial wall rupture. Another aspect that is difficult to explain is the near normal blood pressure in this case at the time of admission.

Mao and colleagues ${ }^{17}$ reported six case of CVA in their cohort of 214 patients. There were five ischemic and one case of hemorrhagic stroke. The French cohort had three cases of ischemic strokes which were detected on neuroimaging when the patients underwent imaging for encephlaophathy ${ }^{19}$. The patients did not have focal neurological signs. Probably the symptoms were masked due to presence of encephalopathy, but it highlights the importance of neuroimaging in evaluation of such cases. However more evidence is needed to establish a causal relationship between stroke and COVID-19.

\section{Acute myelitis}

Zhao et $\mathrm{al}^{33}$ reported acute myelitis in a 66-year-old male from Wuhan city who presented with fever and 
body aches. During the admission he developed acute flaccid paralysis of bilateral lower limbs, sensory level at T-10 with urinary and bowel incontinence. CT scan chest confirmed patchy pneumonia and PCR for nasopharyngeal secretion was positive for COVID-19 infection. His serology for all other organism was negative. He was treated empirically with IVIG, steroids, antibiotics and antiviral. The response to treatment was good and he was discharged to an isolation facility for further rehabilitation. The authors attributed acute myelitis to the cytokine storm and overactive inflammatory response as evident by high levels of serum ferritin, C-reactive protein, Serum Amyloid-A and Interleukin-6 levels.

A major limitation of this case report is the lack of CSF PCR for coronavirus and MRI imaging of spine due to epidemic in Wuhan city.

\section{Headache and dizziness}

Headaches and dizziness are a nonspecific and minor symptoms of many diseases. They have been reported as minor symptoms associated with presentation of COVID-19 in different reports. The incidence ranges from 3 to $12.1 \% 21,35,36$. The detailed mechanism and pathophysiology has not been discussed in any of these reports.

\section{Peripheral nervous system manifestation}

\section{Anosmia and ageusia}

Yan et $\mathrm{al}^{37}$ from USA, documented chemosensory dysfunction in 59 COVID-19 positive and 203 COVID19 negative patients from a single center using an internet based cross sectional survey. They demonstrated that the smell and taste dysfunction was higher in the COVID-19 positive cases as compared to the negative cases (smell loss: $68 \%$ vs. $16 \%$ and taste loss: $71 \%$ vs. $17 \%, \mathrm{p}<0.001)$. Most of the patients in this study were ambulatory, did not need hospitalization and none required mechanical ventilation. They hypothesized that probably in ambulatory COVID-19 patients virus spreads via the nasal route as compared to the seriously ill patients in which the spread is most likely pulmonary. Bagheri et $\mathrm{al}^{38}$ attempted to find a correlation between increased incidence of anosmia. They found significant correlation between anosmia and COVID-19 positivity in different provinces of Iran (Spearman correlation coefficient: 0.87 , p-Value $<0.001$ ). Furthermore, those with anosmia were more likely to have dysgeusia and without typical fever/cough/dyspnea symptoms. In contrast the study by Mao et $\mathrm{al}^{17}$ in their cohort of 214 Chinese patients reported impairment of taste in $12(5.6 \%)$ and impairment of smell in $11(5.1 \%)$ patients only. Anosmia and taste dysfunction were not reported in the French cohort of COVID-19 patients.

\section{Guillain-Barre syndrome (GBS) and variants}

Few cases of COVID-19 associated GBS and its variants have been reported from China, Iran, Italy and Spain. Zhao et $\mathrm{al}^{39}$ reported the first case of GBS in a 61 years old female who presented with acute weakness of both legs and severe fatigue, progressing within 1 day. Nerve Conduction Studies (NCS) and Electromyography (EMG) were suggestive of demyelinating polyneuropathy. She was treated with IVIG and later on developed respiratory symptoms. She tested positive for COVID-19.

Sedaghat et $\mathrm{al}^{40}$ from Iran reported a 61 -Years old diabetic male who had cough, fever and dyspnea two weeks before presenting with ascending paralysis leading to quadriplegia and facial diplegia. NCS/EMG was suggestive of acute motor sensory axonal neuropathy. He was managed with IVIG. Authors have suggested that GBS should be considered as a neurological complication of COVID-19 since respiratory involvement is common in COVID-19 and can be a risk factor for development of GBS.

Virani and colleagues reported GBS in a 54-Years male from USA ${ }^{41}$. He presented with rapidly progressing ascending paralysis leading to respiratory difficulty. There was no bladder or bowel dysfunction. Reflexes were absent and MRI spine was normal. He had history of diarrhea preceding the acute attack of weakness. He tested positive for COVID-19. He was managed with IVIG and anti-malarial. He responded well and was weaned off from the ventilator. He was discharged to a rehabilitation facility for physical therapy.

Toscano et $\mathrm{al}^{42}$ reported five patients with GBS from Northern Italy. Lower-limb weakness and paresthesia were the main presenting features in four patients, followed by facial weakness, ataxia, and paresthesia in one patient. Four had positive PCR from the nasopharyngeal swab on initial visit and fifth one was initially negative but later turned positive. On NCS/EMG 02 patients had features of demyelinating polyneuropathy while three had axonal polyneuropathy. 
All the patients were treated with IVIG. It was repeated in 02 patients and one patient had plasma exchange. After one week, only one patient was able to ambulate independently and discharged from the hospital.

Gutiérrez-Ortiz et al ${ }^{43}$ described two COVID-19 cases presenting with variants of Guillain-Barré syndrome (GBS) in Madrid, Spain. Their first patient was a 50year-old man who presented with a two-day history of vertical diplopia, perioral paresthesia, and gait instability and was found to be COVID-19 positive from nasopharyngeal PCR. Examination areflexia, right internuclear ophthalmoparesis, and right fascicular oculomotor palsy consistent with Miller-Fisher syndrome. Brain imaging with MRI and CSF laboratory studies as well as CSF culture failed to show any abnormality. The patient was treated with immunoglobulins (IV IgG) and had resolution of all of the symptoms except for anosmia and ageusia at the time of discharge. Their second patient was a 39-yearold man who presented with acute onset of diplopia and had a positive nasopharyngeal SARS-CoV-19 PCR. Physical examination showed loss of DTR and bilateral abducens palsy, consistent with polyneuritis cranialis. Other blood, CSF studies, and imaging were negative except for leucopenia. The patient received supportive outpatient treatment and had complete recovery.

Further large scale studies are required to prove this causal relationship between COVID-19 and GBS and its variants.

\section{Skeletal muscle injury}

Mao et al. ${ }^{17}$ reported skeletal muscle injury in 17 [19.3\%] patients in the severely ill and 6 [4.8\%] patients in the non-severe group. Skeletal muscle injury was defined as patient having myalgia and elevated serum creatine kinase level above $200 \mathrm{U} / \mathrm{L}$. They concluded that it was not clear whether this was due to the direct effect of virus on muscle tissue. The other possible mechanism proposed was the infection-mediated immune response causing elevated pro-inflammatory cytokines in serum resulting in skeletal muscle damage. However, it is important to note that patients in the severely ill group in addition to raised muscle enzymes, also had elevated liver enzymes and deranged renal functions which could have contributed to the this clinical picture. Moreover, no specific diagnostic workup for confirmation like NCS/ EMG or muscle histopathology was performed.
Therefore, it is difficult to rule out the possibility of critical illness myopathy and neuropathy in addition to skeletal muscle damage. Guan and co-workers ${ }^{44}$ in their retrospective study showed preliminary evidence of skeletal muscle injury associated with COVID-19 infection among 1099 patients from 550 hospitals in mainland China through January 2020. They found the prevalence of myalgias to be $14.9 \%$ amongst patients, with the rate increasing with the severity of illness. They also reported higher creatinine kinase (CK) levels greater than $200 \mathrm{U} / \mathrm{L}$ among $12.5 \%$ of nonsevere and $19 \%$ of severe cases. Only $0.2 \%$ were caused due to rhabdomyolysis.

\section{Other manifestations}

Mao et al. ${ }^{17}$ also reported neuralgia in five patients and epilepsy and ataxia in one each, but further details were not mentioned.

\section{Experience of COVID-19 in the National Institute of Neurosciences Bangladesh:}

The first case of COVID-19 was detected in Bangladesh on $8^{\text {th }}$ March 2020. Since then till $30^{\text {th }}$ May 2020, 44608 cases have been detected with a death toll of 610 . National Institute of Neuroscience and Hospital is a tertiary Neurology referral center, the only of its kind in Bangladesh. It is a 400 bedded Government hospital which is not designated for COVID 19 pateints. But with the increase in the number of COVID patients in the country a lot of patients were found to have a positive COVID test during their stay in the hospital.

The COVID test was done in the hospitalized patients based on various symptoms of COVID like fever, cough, respiratory distress in addition to their neurological problem and also suspicious chest $\mathrm{x}$-ray findings and blood count (lymphopenia). The test was done in 191 patients till $27^{\text {th }}$ May of which $53(27.7 \%)$ turned out positive.

The mean age $( \pm \mathrm{SD})$ of the positive patients were 46.4 ( \pm 25.43 ) years (range 1 to 85 years) with $62.3 \%$ (33) male and $37.7 \%$ (20) female with a ratio of M:F 1.65:1. Most of the patients got admitted in the hospital with the complaints of hemiplegia [30 (56.6\%)], acute confusional state [12(22.64\%)], altered mental status [7(13.20\%)], weakness of all four limbs [2(3.77\%)], weakness of both lower limbs [1(1.88\%)], seizure [1 $(1.88 \%)]$. The neurological diagnosis was stroke [29(54.71\%)], subdural empyema [1(1.88\%)], meningo-encephalitis 
Table-II

Summary of literature of neurological manifestations in COVID-19

\begin{tabular}{|c|c|c|c|}
\hline Author & Study design & Sample size & Findings \\
\hline $\begin{array}{l}\text { Asadi- } \\
\text { Pooya and } \\
\text { Simani }^{45}\end{array}$ & $\begin{array}{l}\text { Systematic } \\
\text { review }\end{array}$ & $\begin{array}{l}\text { Two significant studies of } 214 \text { and } 221 \\
\text { patients respectively. }\end{array}$ & $\begin{array}{l}25 \% \text { of patients exhibited CNS manifestations, } \\
\text { including headache }(13 \%) \text {, dizziness }(17 \%) \text {, and } \\
\text { acute cerebrovascular problems (3\%). } 5 \% \text { of } \\
\text { patients developed acute ischemic stroke, } 0.5 \% \\
\text { developed cerebral hemorrhage, and } 0.5 \% \text { had } \\
\text { cerebral venous sinus thrombosis. }\end{array}$ \\
\hline $\begin{array}{l}\text { Bagheri et } \\
\mathrm{al}^{38}\end{array}$ & $\begin{array}{l}\text { Cross-sectional } \\
\text { study }\end{array}$ & $\begin{array}{l}10069 \text { patients with self-reported } \\
\text { olfactory dysfunction, with a mean age of } \\
32.5 \text { years. }\end{array}$ & $\begin{array}{l}\text { A significant correlation (Spearman correlation } \\
\text { coefficient }=0.87, p<0.001 \text { ) existed between the } \\
\text { number of self-reported olfactory disorders and } \\
\text { reported COVID- } 19 \text { patients. } 76.24 \% \text { of } \\
\text { participants reported sudden onset of anosmia. } \\
83.38 \% \text { of these patients also experienced loss of } \\
\text { taste. }\end{array}$ \\
\hline 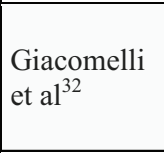 & $\begin{array}{l}\text { Cross-sectional } \\
\text { study }\end{array}$ & $\begin{array}{l}69 \text { COVID-19 positive patients with a } \\
\text { mean age of } 60(50-74) .\end{array}$ & $\begin{array}{l}33.9 \%(20) \text { of patients reported either anosmia or } \\
\text { ageusia, } 18.6 \%(11) \text { reported both. Females more } \\
\text { frequently reported lack of taste or smell }(52.6 \% \\
\text { vs } 25 \%) \text {. }\end{array}$ \\
\hline $\begin{array}{l}\text { Gutiérrez- } \\
\text { Ortiz et al. }\end{array}$ & $\begin{array}{l}\text { Case report } \\
\text { (two patients) }\end{array}$ & $\begin{array}{l}\text { Patient 1: } 50 \text {-year-old man presented to } \\
\text { the emergency room with symptoms of } \\
\text { anosmia and ageusia. Two-day history of } \\
\text { vertical diplopia, perioral paraesthesias, } \\
\text { and gait instability. Patient } 2: 39 \text {-year- } \\
\text { old man was admitted to the ER with } \\
\text { ageusia and onset of diplopia. }\end{array}$ & $\begin{array}{l}\text { Patient 1: Neuro-ophthalmological examination } \\
\text { revealed evidence of right internuclear } \\
\text { ophthalmoparesis and right fascicular oculomotor } \\
\text { palsy. Muscle stretch reflex examination } \\
\text { suggested absence of deep tendon reflexes in } \\
\text { limbs. Evidence of albuminocytologic } \\
\text { dissociation and GD1b-IgG antibody positive. } \\
\text { Findings suggested Miller Fisher } \\
\text { syndrome. Patient 2: Neuro-ophthalmological } \\
\text { exam revealed fixed nystagmus, severe abduction } \\
\text { deficits in both eyes, and esotropia of } 10 \text { prism } \\
\text { diopters (distance) and } 4 \text { prism diopters (near). } \\
\text { All deep tendons reflexes were absent. } \\
\text { Leukopenia present (3100 cells/uL). Findings } \\
\text { suggested polyneuritis cranialis. }\end{array}$ \\
\hline $\begin{array}{l}\text { Helms et } \\
\mathrm{al}^{19}\end{array}$ & Case series & $\begin{array}{l}\text { Prospective case series of } 58 \text { patients } \\
\text { from France }{ }^{19} \text { with a median age of } 63 \\
\text { years. }\end{array}$ & $\begin{array}{l}\text { Neurological complications were seen in } 49 / 58 \\
(84 \%) \text {. As assessed by confusion Assessment } \\
\text { method for intensive care unit CAM-ICU scale, } \\
\text { agitation was the most common symptoms } 40 / 58 \\
(69 \%) \text { followed by confusion } 26 / 40(65 \%) \text {. } \\
\text { Corticospinal tract signs were present in in } 39 / 58 \\
(67 \%) \text { and a dysexecutive syndrome at the time } \\
\text { of discharge was noted in } 14 / 39(36 \%) \text {. }\end{array}$ \\
\hline $\begin{array}{l}\text { Karimi et } \\
\text { al. }^{26}\end{array}$ & Case report & $\begin{array}{l}\text { 30-year-old patient presented in the ER } \\
\text { with a generalized tonic-clonic seizure, } \\
\text { with five more seizures occurring every } \\
\text { eight hours. }\end{array}$ & $\begin{array}{l}\text { Findings included drowsiness with disorientation } \\
\text { to time, normal CSF findings, and functional } \\
\text { deep tendon reflexes. Blood sample revealed } \\
\text { WBC }=5500 \text { cells } / \mathrm{mL} \text { with } 26 \% \text { lymphocytes, } \\
70 \% \text { neutrophils, and ESR }=35 \mathrm{~mm} / \mathrm{h} \text {. }\end{array}$ \\
\hline $\begin{array}{l}\text { Lechien et } \\
\text { al }^{46}\end{array}$ & $\begin{array}{l}\text { Cross-sectional } \\
\text { study }\end{array}$ & $\begin{array}{l}417 \text { COVID-19 positive patients with a } \\
\text { mean age of } 36.9(19-77) .\end{array}$ & $\begin{array}{l}357 \text { patients }(85.6 \%) \text { developed olfactory } \\
\text { dysfunction, with } 284(79.6 \%) \text { with anosmia and } \\
73(20.4 \%) \text { with hyposmia. } 342 \text { patients }(88.8 \%) \\
\text { developed gustatory dysfunction. There was a } \\
\text { significant associated }(0<0.001) \text { between } \\
\text { olfactory and gustatory dysfunctions. Females } \\
\text { were more significantly associated with both } \\
\text { dysfunctions }(p<0.001) \text {. }\end{array}$ \\
\hline
\end{tabular}




\begin{tabular}{|c|c|c|c|}
\hline Author & Study design & Sample size & Findings \\
\hline Li et $\mathrm{al}^{18}$ & $\begin{array}{l}\text { Retrospective } \\
\text { study }\end{array}$ & $\begin{array}{l}221 \text { COVID-19 positive patients with a } \\
\text { mean age of } 53.3(57-91) \text {. }\end{array}$ & $\begin{array}{l}11 \text { patients }(5 \%) \text { were diagnosed with } \\
\text { ischemic stroke, } 1(0.5 \%) \text { with cerebral venous } \\
\text { sinus thrombosis, and one }(0.5 \%) \text { with } \\
\text { cerebral hemorrhage. }\end{array}$ \\
\hline Lu et $\mathrm{al}^{28}$ & $\begin{array}{l}\text { Retrospective } \\
\text { study }\end{array}$ & $\begin{array}{l}302 \text { COVID- } 19 \text { positive patients with a } \\
\text { mean age of } 44 \text {. }\end{array}$ & $\begin{array}{l}\text { Eight patients developed encephalopathy. } 84 \\
(27 \%) \text { patients developed systemic or direct } \\
\text { brain results that increased their risk for } \\
\text { seizures, including hypoxia }(40,13 \%) \text {. } \\
\text { Electrolyte disturbances such as hypokalemia } \\
(40,13 \%) \text {, hyponatremia }(34,11 \%) \text {, and } \\
\text { hypocalcemia }(22,7 \%) \text { were observed. }\end{array}$ \\
\hline Mao et $\mathrm{al}^{17}$ & Case series & $\begin{array}{l}214 \text { COVID-19 positive patients with a } \\
\text { mean age of } 52.7 \text {. }\end{array}$ & 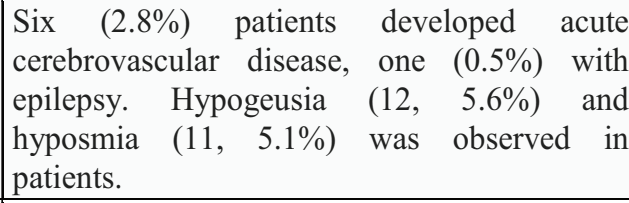 \\
\hline 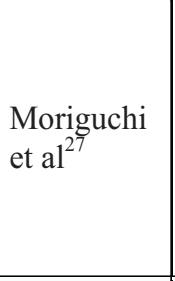 & Case report & $\begin{array}{l}\text { 24-year-old man found unconscious } \\
\text { was brought to the ED with neck } \\
\text { stiffness, headache, and fatigue. Patient } \\
\text { had transient generalized seizures } \\
\text { during transportation. }\end{array}$ & $\begin{array}{l}\text { Findings included hyperintense signals along } \\
\text { the portion of the inferior lobe of the right } \\
\text { ventricle. Hyperintensity was present in the } \\
\text { right mesial temporal lobe and hippocampus. } \\
\text { Slight atrophy of the hippocampus was } \\
\text { present. Findings suggestive of } \\
\text { meningitis/encephalitis. }\end{array}$ \\
\hline $\begin{array}{l}\text { Poyiadji et } \\
\mathrm{al}^{29}\end{array}$ & Case report & $\begin{array}{l}\text { Patient in her late } 50 \text { s presented with a } \\
\text { three-day onset of cough, fever, and } \\
\text { altered mental status. }\end{array}$ & $\begin{array}{l}\text { Non-contrast CT showed hypoattenuation } \\
\text { within the bilateral medial thalamic. Brain } \\
\text { MRI demonstrated hemorrhagic rim enhancing } \\
\text { lesions in three areas: within the bilateral } \\
\text { thalami, medial temporal lobes, and subinsular } \\
\text { regions. Findings suggested hemorrhagic } \\
\text { necrotizing encephalopathy. }\end{array}$ \\
\hline $\begin{array}{l}\text { Sharifi- } \\
\text { Razavi et } \\
\mathrm{al}^{30}\end{array}$ & Case report & $\begin{array}{l}\text { 79-year-old patient presented with a } \\
\text { three-day cough and loss of } \\
\text { consciousness. }\end{array}$ & $\begin{array}{l}\text { Brain CT revealed a serious intercerebral } \\
\text { hemorrhage in the right hemisphere, as well as } \\
\text { evidence of intraventricular and subarachnoid } \\
\text { hemorrhage. }\end{array}$ \\
\hline Zhao et $\mathrm{al}^{39}$ & Case report & $\begin{array}{l}\text { 61-year-old female presented with } \\
\text { weakness in both legs and fatigue. } \\
\text { Patient was tested for COVID-19 due } \\
\text { to a developed dry cough and fever } \\
\text { after eight days of weakness. }\end{array}$ & $\begin{array}{l}\text { Neurological exams revealed weakness and } \\
\text { areflexia in legs and feet. After three days, } \\
\text { muscle strength was } 4 / 5 \text { in both arms and } \\
\text { hands, sensation to pinprick and light touch } \\
\text { decreased distally. On day } 5 \text {, nerve conduction } \\
\text { studies showed absent } F \text { waves and delayed } \\
\text { distal latencies. Patient was diagnosed with } \\
\text { Guillain-Barré syndrome. }\end{array}$ \\
\hline Zhao et $\mathrm{al}^{33}$ & Case report & $\begin{array}{l}\text { 66-year old man was admitted to the } \\
\text { ICU for weakness in the lower limbs } \\
\text { and urinary and bowel incontinence, } \\
\text { shortly after experiencing fever and } \\
\text { fatigue for seven days. }\end{array}$ & $\begin{array}{l}\text { Neurological examination revealed } 3 / 5 \\
\text { strength in the upper extremities and } 0 / 5 \\
\text { strength in the lower extremities. Hyporeflexia } \\
\text { was apparent in the lower limbs. Sensations } \\
\text { were intact in the arms but impaired in the } \\
\text { legs. Findings suggest acute myelitis. }\end{array}$ \\
\hline $\begin{array}{l}\text { Guan et } \\
\mathrm{al}^{44}\end{array}$ & $\begin{array}{l}\text { Retrospective } \\
\text { study }\end{array}$ & $\begin{array}{l}1099 \text { COVID-19 positive patients with } \\
\text { a mean age of } 47.0(35.0-58.0) .\end{array}$ & $\begin{array}{l}\text { Creatinine kinase levels } \\
\text { observed in } 12.5 \%(67 / 536) \text { of nonsevere and } \\
19 \% \quad(23 / 121) \text { of severe patients. } \\
\text { Rhabdomyolysis in two patients }(0.2 \%) .\end{array}$ \\
\hline
\end{tabular}


Table-III

Clinico-demographic profile of the hospitalized COVID-19 positive patients:

\begin{tabular}{|c|c|}
\hline Age & - $\quad 46.4( \pm 25.43)$ years (range 1 to 85 years) \\
\hline Sex & $\begin{array}{ll} & \text { Male } 33(62.3 \%) \\
\text { - } & \text { Female } 20(37.7 \%) \\
\text { - } & \text { M:F 1.65:1. }\end{array}$ \\
\hline Presenting neurological symptoms & $\begin{array}{ll}\text { - } & \text { Hemiplegia }[30(56.60 \%)] \\
\text { - } & \text { Acute confusional state }[12(22.64 \%)] \\
\text { - } & \text { Altered mental status }[7(13.20 \%)] \\
\text { - } & \text { Weakness of all four limbs }[2(3.77 \%)] \\
\text { - } & \text { Weakness of both lower limbs }[1(1.88 \%)] \\
\text { - } & \text { Seizure }[1(1.88 \%)]\end{array}$ \\
\hline Neurological diagnosis & $\begin{array}{ll}\text { - } & \text { Stroke }[29(54.71 \%)] \\
\text { - } & \text { Subdural empyema }[1(1.88 \%)] \\
\text { - } & \text { Meningo-encephalitis }[15(65.21 \%)] \\
\text { - } & \text { Guillain-Barre syndrome }[3(5.66 \%)] \\
\text { - } & 5 \text { patients expired before the completion of diagnostic } \\
& \text { workup }\end{array}$ \\
\hline
\end{tabular}

[15(65.21\%)], Guillain-Barre syndrome [3(5.66\%)] and 5 patients expired before the completion of diagnostic workup (Table 3).

It was not possible to establish whether COVID-19 was a mere coincidence in the perspective of large-scale ongoing community transmission or it has any causal relationship with the diagnosis. Large scale studies are warranted to establish the fact.

\section{Conclusion:}

It has become clear from the different studies so far published, that COVID-19 has protean of neurological manifestations. Prompt recognition and early institution of therapy will minimize complications. Complications are more common in severely ill patients. Sometimes neurological symptoms may be the only presentation and many a times they can even precede other symptoms. So a high index of suspicion is required for prompt treatment. Large scale study from different parts of the world will lead to a better understanding of the complications which in turn would help in developing consensus regarding better treatment modalities.

\section{References:}

1. Zhu N, Zhang D, Wang W, Li X, Yang B, Song J, Zhao X, Huang B, Shi W, Lu R, Niu P. A novel coronavirus from patients with pneumonia in China, 2019. New England
Journal of Medicine. 2020 Jan 24. DOI: 10.1056/ NEJMoa2001017

2. Green A. Li wenliang. The Lancet. 2020 Feb 29; 395(10225):682. DOI: https://doi.org/10.1016/S01406736(20)30382-2

3. World Health Organization. Pneumonia of unknown cause - China. Disease outbreak news. 5 January 2020 Available at https://www.who.int/csr/don/05-january-2020pneumonia-of-unkown-cause-china/en

4. WHO Director-General's opening remarks at the media briefing on COVID-19 - 11 March 2020. 11 March 2020. Available at https://www.who.int/dg/speeches/detail/whodirector-general-s-opening-remarks-at-the-mediabriefingon-covid-19-11-march-2020.

5. Publishing research during pandemics: are you vulnerable to the COVID-19 or predatory publishers? J Pak Med Assoc. 2020; 70 (In press)

6. Di Gennaro F, Pizzol D, Marotta C, Antunes M, Racalbuto V, Veronese N, Smith L. Coronavirus diseases (COVID-19) current status and future perspectives: A narrative review. International journal of environmental research and public health. 2020 Jan;17(8):2690. https://doi.org/10.3390/ ijerph 17082690 .

7. Tu H, Tu S, Gao S, Shao A, Sheng J. The epidemiological and clinical features of COVID-19 and lessons from this global infectious public health event. Journal of Infection. 2020 Apr 18. https://doi.org/10.1016/j.jinf.2020.04.011. pii: S0163-4453(20)30222-X. 
8. Li Xiaowei, Geng Manman, Peng Yizhao, Meng Liesu, Lu Shemin. Molecular immune pathogenesis and diagnosis of COVID-19. J Pharm Anal 2020;10(2):102-8. https:// doi.org/10.1016/j.jpha.2020.03.001

Desforges M, Le Coupanec A, Dubeau P, Bourgouin A, Lajoie L, Dubé M, Talbot PJ. Human Coronaviruses and Other Respiratory Viruses: Underestimated Opportunistic Pathogens of the Central Nervous System?. Viruses. 2020 Jan;12(1):14.

9. Bohmwald K, Galvez N, Ríos M, Kalergis AM. Neurologic alterations due to respiratory virus infections. Frontiers in cellular neuroscience. 2018 Oct 26;12:386.

10. Baig AM, Khaleeq A, Ali U, Syeda H. Evidence of the COVID-19 virus targeting the CNS: tissue distribution, host virus interaction, and proposed neurotropic mechanisms. ACS Chemical Neuroscience. 2020 Apr 1;11(7):995-8.

11. Steardo L, Steardo Jr L, Zorec R, Verkhratsky A. Neuroinfection may contribute to pathophysiology and clinical manifestations of COVID 19. Acta Physiologica. 2020 Mar 29:e13473.Mar 29:e13473. DOI: 10.1111/ apha.13473

12. Li Yan-Chao, Bai Wan-Zhu, Hashikawa Tsutomu. The neuroinvasive potential of SARS-CoV2 may play a role in the respiratory failure of COVID-19 patients. J Med Virol 2020;92(6):552-5. https://doi.org/10.1002/jmv.v92.6.

13. Abdennour L., Zeghal C., Deme M., Puybasset L. Interaction brain-lungs. Ann. Fr. Anesth. Reanim.2012;31(6):e101-107

14. Mehta P, McAuley DF, Brown M, Sanchez E, Tattersall RS, Manson JJ. HLH across speciality collaboration, UK. COVID-19: consider cytokine storm syndromes and immunosuppression. Lancet 2020; 395(10229):1033-4.

15. Tveito K. Cytokine storms in COVID-19 cases? Tidsskr Nor Laegeforen 2020 Mar; 23:140. https://doi.org/10.4045/ tidsskr.20.0239.

16. Mao L, Jin H, Wang M, Hu Y, Chen S, He Q, Chang J, Hong C, Zhou Y, Wang D, Miao X. Neurologic manifestations of hospitalized patients with coronavirus disease 2019 in Wuhan, China. JAMA neurology. 2020 Apr 10. https:// doi.org/10.1001/jamaneurol.2020.1127.

17. Li Y, Wang M, Zhou Y, et al.: Acute cerebrovascular disease following COVID- 19: a single center, retrospective, observational study. Social Sci Res Netw Electr J. 2020,

18. Helms J, Kremer S, Merdji H, Clere-Jehl R, Schenck M, Kummerlen C, Collange O, Boulay C, Fafi-Kremer S, Ohana M, Anheim M. Neurologic features in severe SARS-CoV-2 infection. New England Journal of Medicine. 2020 Apr 15. DOI: $10.1056 / \mathrm{NEJMc} 2008597$

19. Chen N, Zhou M, Dong X, Qu J, Gong F, Han Y, Qiu Y, Wang J, Liu Y, Wei Y, Yu T. Epidemiological and clinical characteristics of 99 cases of 2019 novel coronavirus pneumonia in Wuhan, China: a descriptive study. The
Lancet. 2020 Feb 15; 395(10223):507-13. DOI: 10.1016/ S0140-6736(20)30211-7

20. Huang C, Wang Y, Li X, Ren L, Zhao J, Hu Y, Zhang L, Fan $\mathrm{G}, \mathrm{Xu} J$, Gu X, Cheng Z. Clinical features of patients infected with 2019 novel coronavirus in Wuhan, China. The lancet. 2020 Feb 15; 395(10223):497-506. https://doi.org/ 10.1016/S2213-2600(20)30079-5

21. Yang X, Yu Y, Xu J, Shu H, Liu H, Wu Y, Zhang L, Yu Z, Fang M, Yu T, Wang Y. Clinical course and outcomes of critically ill patients with SARS-CoV-2 pneumonia in Wuhan, China: a single-centered, retrospective, observational study. The Lancet Respiratory Medicine. 2020 Feb 24. DOI: 10.1016/S2213-2600(20)30079-5

22. Wang D, Hu B, Hu C, Zhu F, Liu X, Zhang J, Wang B, Xiang $\mathrm{H}$, Cheng Z, Xiong Y, Zhao Y. Clinical characteristics of 138 hospitalized patients with 2019 novel coronavirusinfected pneumonia in Wuhan, China. Jama. 2020 Mar 17; 323(11):1061-9. DOI: 10.1001/jama.2020.1585

23. $\mathrm{Xu} X-\mathrm{W}, \mathrm{Wu} \mathrm{X}-\mathrm{X}$, Jiang $\mathrm{X}-\mathrm{G}$, et al.: Clinical findings in a group of patients infected with the 2019 novel coronavirus (SARS-Cov-2) outside of Wuhan, China: retrospective case series. BMJ. 2020 Feb 19, 368. DOI:10.1136/bmj.m606

24. Filatov A, Sharma P, Hindi F, et al.: Neurological complications of coronavirus disease (COVID- 19): encephalopathy. Cureus J Med Sci. 2020, 12:10.7759/ cureus. 7352

25. Karimi N, Sharifi Razavi A, Rouhani N. Frequent convulsive seizures in an adult patient with COVID-19: a case report. Iranian Red Crescent Medical Journal. 2020 Mar (In Press). DOI: $10.5812 /$ ircmj. 102828

26. Moriguchi T, Harii N, Goto J, et al.: A first case of meningitis/encephalitis associated with SARS-Coronavirus2. Int J Infect Dis IJID Off Publ Int Soc Infect Dis. 2020, 94:55-58. DOI: $10.1016 /$ j.ijid.2020.03.062

27. Lu L, Xiong W, Liu D, Liu J, Yang D, Li N, Mu J, Guo J, Li W, Wang G, Gao H. New onset acute symptomatic seizure and risk factors in Corona Virus Disease 2019: A Retrospective Multicenter Study. Epilepsia. 2020 Apr 18. DOI:10.1111/epi.16524

28. Poyiadji N, Shahin G, Noujaim D, Stone M, Patel S, Griffith B. COVID-19-associated acute hemorrhagic necrotizing encephalopathy: CT and MRI features. Radiology. 2020 Mar 31:201187. DOI: 10.1148/radiol.2020201187

29. Sharifi-Razavi A, Karimi N, Rouhani N. COVID-19 and intracerebral haemorrhage: causative or coincidental?. New microbes and new infections. 2020 May; 35. DOI: 100669. 10.1016/j.nmni.2020.100669

30. Chen T, Wu D, Chen H, Yan W, Yang D, Chen G, Ma K, Xu D, Yu H, Wang H, Wang T. Clinical characteristics of 113 deceased patients with coronavirus disease 2019: retrospective study. BMJ. 2020 Mar 26;368. DOI: https:// doi.org/10.1136/bmj.m1091. Erratum in: BMJ. 2020 Mar 31;368: m1295. 
31. Giacomelli A, Pezzati L, Conti F, Bernacchia D, Siano M, Oreni L, Rusconi S, Gervasoni C, Ridolfo AL, Rizzardini G, Antinori S. Self-reported olfactory and taste disorders in patients with severe acute respiratory coronavirus 2 infection: a cross-sectional study. Clinical Infectious Diseases. 2020 Mar 26.

32. Zhao K, Huang J, Dai D, Feng Y, Liu L, Nie S. Acute myelitis after SARS-CoV-2 infection: a case report. MedRxiv. 2020 Jan 1.

33. Huang C, Wang Y, Li X, Ren L, Zhao J, Hu Y, Zhang L, Fan $\mathrm{G}, \mathrm{Xu}$ J, Gu X, Cheng Z. Clinical features of patients infected with 2019 novel coronavirus in Wuhan, China. The lancet. 2020 Feb 15;395(10223):497-506. https://doi.org/10.1016/ S2213-2600(20)30079-5

34. Deng Y, Liu W, Liu K, Fang YY, Shang J, Wang K, Leng F, Wei S, Chen L, Liu HG. Clinical characteristics of fatal and recovered cases of coronavirus disease 2019 (COVID-19) in Wuhan, China: a retrospective study. Chinese medical journal. 2020 Apr 21. https://doi.org/10.1097/

35. Li LQ, Huang T, Wang YQ, Wang ZP, Liang Y, Huang TB, Zhang HY, Sun W, Wang Y. COVID 19 patients' clinical characteristics, discharge rate, and fatality rate of meta analysis. Journal of medical virology. 2020 Jun; 92(6):57783. https://doi.org/10.1002/jmv.25757

36. Yan CH, Faraji F, Prajapati DP, Boone CE, DeConde AS. Association of chemosensory dysfunction and Covid 19 in patients presenting with influenza like symptoms. In International forum of allergy \& rhinology 2020 Apr 12 . https://doi.org/10.1002/alr.22579

37. Bagheri SH, Asghari AM, Farhadi M, Shamshiri AR, Kabir A, Kamrava SK, Jalessi M, Mohebbi A, Alizadeh R, Honarmand AA, Ghalehbaghi B. Coincidence of COVID19 epidemic and olfactory dysfunction outbreak. Medrxiv. 2020 Jan 1. 2020. DOI: 10.1101/2020.03.23.20041889

38. Zhao H, Shen D, Zhou H, Liu J, Chen S. Guillain-Barré syndrome associated with SARS-CoV-2 infection: causality or coincidence?. The Lancet Neurology. 2020 May 1;19(5):383-4. https://doi.org/10.1016/S1474-4422(20) 30109-5

39. Sedaghat Z, Karimi N. Guillain Barre syndrome associated with COVID-19 infection: A case report. Journal of Clinical Neuroscience. 2020 Apr 15.

40. Virani A, Rabold E, Hanson T, Haag A, Elrufay R, Cheema T, Balaan M, Bhanot N. Guillain-Barré syndrome associated with SARS-CoV-2 infection. IDCases. 2020 Apr 18:e00771.

41. Toscano G, Palmerini F, Ravaglia S, Ruiz L, Invernizzi P, Cuzzoni MG, Franciotta D, Baldanti F, Daturi R, Postorino P, Cavallini A. Guillain-Barré syndrome associated with SARS-CoV-2. New England Journal of Medicine. 2020 Apr 17. https://doi.org/ 10.1056/NEJMc2009191.

42. Gutiérrez-Ortiz C, Méndez A, Rodrigo-Rey S, San PedroMurillo E, Bermejo-Guerrero L, Gordo-Mañas R, de AragónGómez F, Benito-León J. Miller Fisher Syndrome and polyneuritis cranialis in COVID-19. Neurology. $2020 \mathrm{Apr}$ 16 .

43. Guan WJ, Ni ZY, Hu Y, Liang WH, Ou CQ, He JX, Liu L, Shan H, Lei CL, Hui DS, Du B. Clinical characteristics of coronavirus disease 2019 in China. New England journal of medicine. 2020 Apr 30;382(18):1708-20.

44. Asadi-Pooya AA, Simani L. Central nervous system manifestations of COVID-19: A systematic review. Journal of the Neurological Sciences. 2020 Apr 11:116832. 10.1016/j.jns.2020.116832

45. Lechien JR, Chiesa-Estomba CM, De Siati DR, Horoi M, Le Bon SD, Rodriguez A, Dequanter D, Blecic S, El Afia F, Distinguin L, Chekkoury-Idrissi Y. Olfactory and gustatory dysfunctions as a clinical presentation of mild-to-moderate forms of the coronavirus disease (COVID-19): a multicenter European study. European Archives of Oto-RhinoLaryngology. 2020 Apr 6:1-1. 10.1007/s00405-02005965-1 